\title{
California to keep energy labs contracts
}

Washington. The US Department of Energy (DoE), in a decision that appears tinged with election-year politics, announced last week it will not put up for competitive bidding the contracts now held by the University of California (UC) for operating its three national laboratories - Lawrence Livermore, Lawrence Berkeley and Los Alamos - when the current agreements expire next year.

Senior DoE officials deny that political considerations have been involved in the decision. Nevertheless, the announcement includes a highly unusual congratulatory statement to the university from President Bill Clinton. And Charles Curtis, DoE's Deputy Secretary, mentioned Clinton's support for the university several times.

"Over the last five decades, the University of California made an enormous contribution to our success in winning the Cold War," Clinton said in his statement. "We look forward to working with [UC] to promote both our economic and national security."

Winning votes in California is crucial to Clinton's bid for re-election. "You're going

\section{Ministry merger prompts fears in Italy}

Munich. Italy's ministry for universities and research, created only eight years ago to promote the needs of higher education and research more effectively, has been merged by the new centre-left coalition government with the much larger ministry of public education.

As part of the cabinet appointments announced last week, 57-year-old Luigi Berlinguer, a professor of law at the University of Siena, and head of the parliamentary group of the PDS, the former communist party which is now the largest party in the new parliament, will become minister for education and research.

Berlinguer has many years of experience in parliament, and is widely respected as a competent and efficient administrator. But the merger of the ministries has raised concern in the Italian scientific community that the needs of research could become submerged by the sheer weight of the new super-ministry.

Glauco Tocchini-Valentini, director of the CNR Institute of Cell Biology in Rome, argues that research "did not receive the necessary attention in the negotiations to form the new government". Similarly, Luciano Maiani, president of the INFN, the Italian nuclear physics research organization, told the daily paper L'Unita that the new ministry's task would be "very difficult", and he feared one of the two sides - either education or research - may suffer.

Romano Prodi, the new prime minister, who at one point was believed to favour the to see everything going to California that can go there" in the next several months, according to one Republican source, who points out that former President George Bush also steered contracts to the state during his failed 1992 re-election bid.

But Curtis insists the department had decided to stick with the University of California solely for non-political reasons, the most important of which, he says, is the need to maintain "continuity of management" at the two nuclear weapons laboratories - Los Alamos and Livermore - at a "sensitive time" in the post-Cold-War environment. "This is not a political issue by state," says Curtis. "This is not huge money to the University of California system; this is a service to the nation, as [UC] will emphasize."

The university has operated the laboratories since their inception, and receives about $\$ 20$ million a year to operate the three facilities. DoE said it would negotiate fiveyear extensions for all three facilities, which together cost $\$ 2.5$ billion a year to run.

According to Curtis, avoiding disruption at the weapons laboratories is especially former research minister, Antonio Ruberti, for the research post, has given no specific reason for his decision to combine the ministries, although it does help to reduce the total number of government departments.

A similar merger took place in Germany eighteen months ago, when the ministries of research and education were combined to form the grandly titled 'ministry of the future'. But the German scientific community still feels that this merger has reduced the political priority given to research.

Alison Abbott important in the light of DoE's need rapidly to put into place the elements of its "science-based stockpile management" programme for ensuring the reliability and safety of the nuclear arsenal without underground testing. These include the "accelerated strategic computing initiative" aimed at improving the modelling of nuclear weapons explosions, as well as new experimental instruments such as the National Ignition Facility, a \$1.1-billion laser fusion device to be built at Livermore.

While management of the third weapons laboratory, Sandia National Laboratories now operated by the giant defence contractor Lockheed Martin Corporation - changed hands in 1993 with scarcely a ripple, Curtis maintained that a change at the UC laboratories would be much more disruptive. The research and development work at Sandia, which concerns the electronic and other non-nuclear components of nuclear weapons, "lends itself more to a conventional for-profit contractor," he says.

The university's management of Los Alamos came under fire last year from two Democratic members of New Mexico's congressional delegation for its lack of involvement with the local community. Representative Bill Richardson and Senator Jeff Bingaman had urged the DoE to solicit other bidders for the management contract, although Richardson later changed his mind.

Reflecting such concern, the extension of the Los Alamos contract will be conditional on a commitment by UC to tackle community development issues in northern New Mexico. The university will also be required to make unspecified management changes to improve operation of the laboratory's 'non-core' activities, such as environmental clean-up activities and safety and health operations.

David Kramer

\section{Satellite quartet tunes up for the big night}

\author{
IMAGE \\ UNAVAILABLE \\ FOR COPYRIGHT \\ REASONS
}

London. The four European satellites (two are stacked on the right) that are due to be launched together next week by the European Space Agency's new Ariane-5 rocket to study the interactions between the solar wind and the near-Earth environment. The socalled Cluster quartet will gather information on the magnetic storms, electric currents and particle accelerations that occur in the space surrounding the Earth.

The satellites, seen here in Munich before being shipped to the launch site in Kourou in French Guyana, will also collect data on the ionized gases whose behaviour physicists are trying to reproduce in the laboratory to generate thermonuclear energy. Once in space, they will move into an eccentric polar trajectory around the Earth, which they will then follow in tetrahedral formation for the next two years. 